\title{
External Influence as an Indicator of Scholarly
}

\section{Importance}

\author{
by \\ Ho Fai Chan, Bruno S. Frey, Jana Gallus, Markus Schaffner, Benno Torgler, and Stephen \\ Whyte*
}

\begin{abstract}
The external influence of scholarly activity has to date been measured primarily in terms of publications and citations, metrics that also dominate the promotion and grant processes. Yet the array of scholarly activities visible to the outside world are far more extensive and recently developed technologies allow broader and more accurate measurement of their influence on the wider societal discourse. Accordingly we analyze the relation between the internal and external influences of 723 top economics scholars using the number of pages indexed by Google and Bing as a measure of their external influence. Although the correlation between internal and external influence is low overall, it is highest among recipients of major key awards such as the Nobel Prize or John Bates Clark medal, and particularly strong for those ranked among the top 100 researchers.
\end{abstract}

Keywords: Academia, Scholarly Importance, Role of Economics, Social Importance of Economists, External and Internal Influence, Academic Performance, Awards. JEL Code: A11, A13, Z18, Z19

\footnotetext{
* Ho Fai Chan, Markus Schaffner and Stephen Whyte: Queensland Behavioural Economics Group (QuBE), School of Economics and Finance, Queensland University of Technology; Bruno S. Frey: Warwick Business School, University of Warwick and Department of Economics, Zeppelin University; Jana Gallus, Department of Economics, University of Zurich; Benno Torgler: Queensland Behavioural Economics Group (QuBE), School of Economics and Finance, Queensland University of Technology, and EBS Business School, ISBS, EBS Universität für Wirtschaft und Recht. Frey and Torgler: CREMA - Center for Research in Economics, Management and the Arts. Corresponding author: Benno Torgler (benno.torgler@qut.edu.au).
} 


\section{INTRODUCTION}

The primary metric currently used in the extensive literature regarding influences on scholarly production is the number of publications and, perhaps more appropriately, number of citations in academic journals. This approach also dominates the rankings of both individual researchers and departments and universities. Yet this metric only considers the impact of scholarly activity within academia, as reflected in scholarly publications that are themselves defined rather narrowly. For example, collections of general academic publications and citations only cover a restricted set of publication outlets (excluding books, pamphlets, reports, and newspapers), while appointment as a university researcher often depends only on the number of publications in "top-tier" academic journals.

Meanwhile, it is generally acknowledged that a scholar's responsibilities and functions span a far broader array of activities, which can be categorized under four rubrics: (1) scholarly publication including activities as referee, editor, or board member , (2) teaching, (3) academic self-governance (e.g., serving as department head or dean), and (4) influence on the broader society. Whereas two of these four activity types - scholarly publication and academic self-governance - are internal to the university community, influence on the broader society is external. On the other hand, teaching is a mix of the two: although an internal activity, it has an external impact via the influence exerted by students after graduation; most particularly, in terms of professional position (e.g., as company CEO or government minister).

In fact, many scholarly institutions have an explicitly stated goal of participating in the wider societal discourse, although this goal differs between disciplines and subdisciplines, as well as between countries. For instance, although the general public does not usually expect theoretical physicists to directly impact society, it does expect applied physicists to make a contribution, albeit perhaps at a lower level than social scientists although one could stress that there are more industry partnerships in hard sciences than in social sciences. To economists, it even ascribes the ability to predict the future course of the economy, indicating the high expectations held by the general public. For example, while being briefed on the turmoil on the international markets by academics during a 2008 visit to the London School of Economics, Queen Elizabeth asked why nobody noticed the trouble coming. Even though Professor Luis Garicano, director of research at the school’s management department, "had explained the origins and effects of the credit crisis when she opened the $£ 71$ million New 
Academic Building, the Queen, who studiously avoids controversy and never gives away her opinions, then described the turbulence on the markets as 'awful'."1

To answer the Queen's question, it is crucial to understand how internal activities within academia relate to the outside world, and in particular, to the economy. ${ }^{2}$ Yet views on this matter diverge strongly. For example, Barro (1996) suggests (perhaps jokingly) that there is no relation between the state of the U.S. economy and the quality of the economists on the U.S. Council of Economic Advisors:

... economic outcomes (measured by the contribution to the misery index) and the credentials of the chairman of the council (measured by the citation count) are uncorrelated. Although some who are highly ranked on citations . . . do well on performance, the highly ranked Schultze ends up with the worst economic outcomes. Moreover, some of the chairpersons who are ranked relatively low on citations ... emerge with good economic performance. (pp. 88-89)

Many academic economists, on the other hand, although convinced that economics does have an effect on society, are skeptical about whether this influence is beneficial. Galbraith (1975), for instance, complained four decades ago that "the economic profession - I choose the words with care - is intellectually bankrupt. It might as well not exist” (cited in Nadeau (2003), p. 185). Even more surprisingly, Friedman (1972, p. 12), speaking from the opposite side of the ideological spectrum, concurred: "We economists in recent years have done vast harm - to society at large and to our profession in particular - by claiming more than we can deliver”. As shown below, these negative perceptions have persisted.

Many statements to this effect are also evident in the press, including serious economics magazines. The Economist, for example, has in several instances mused about the “Puzzling Failure of Economics” (1997, p. 13) even alluding to Keynes’s famous dictum by asking, "In the long run, is the subject dead?” (Economist, 2000, p. 90), Likewise, a writer for the New Yorker comments that “. . . a good deal of modern economic theory, even the kind that wins Nobel Prizes, simply does not matter much” (Cassidy 1996, pp. 50-51).

Although some may argue that journalistic statements need not to be taken seriously,

\footnotetext{
${ }^{1}$ Andrew Pierce, "The Queen asks why no one saw the credit crunch coming.” The Telegraph, 5 November, 2008. See also the letter to the Queen signed, among others, by Tim Besley and Peter Hennessy, which reportedly states that “'financial wizards' who believed that their plans to manage risky debts and protect the financial system were infallible were guilty of "wishful thinking combined with hubris"” (http://www.smh.com.au/business/economists-apologise-to-queen-elizabeth-ii-20090727-dxpo.html).

${ }^{2}$ See also the related discussion in Frey (2006).
} 
similar views have even been advanced among academic economists. For example, Clower (1993, p. 23), a former editor of the American Economic Review, states that "(m)uch of economics is so far removed from anything that remotely resembles the real world that it is often difficult for economists to take their subject seriously”. In fact, Karier (2010), in a review of 40 years of the Nobel Prize in economics, makes the following claim:

Few of the Nobel laureates mentioned in this book were ever particularly famous, except for those who wrote for general audiences such as Milton Friedman, Paul Krugman, and Paul Samuelson. For many winners, the most fame they ever achieved was the day they won the Nobel Prize. The majority of Nobel laureates in economics were academics whose lives revolved around universities run by provosts, deans, and department chairs. They were accustomed to presenting their ideas in conferences, academic journals, graduate seminars, and scholarly texts, where brevity and clarity were less valued than mathematical rigor and abstract generality. (p. 11)

Moreover, even Nobel Prize recipients in economics, such as Leontief (1971), Coase (1994), and Buchanan (2000) criticized their field for its lack of involvement in real life issues. The most devastating judgment was advanced by Blaug (1997): “Modern economics is sick; economics has increasingly become an intellectual game played for its own sake and not for its practical consequences ....” (p. 3).

Yet several important economists propagate the opposite view, typified by Keynes’ (1936) famous claim that "the ideas of economists and political philosophers . . . are more powerful than is commonly understood. Indeed the world is ruled by little else” (p. 383). Even his intellectual opponent Hayek (1991) agrees, although he qualifies the claim somewhat: “economists have this great influence only in the long run and indirectly” (p. 37). More recently, similar views of economics' considerable impact on society have been put forward by Dasgupta (1998) and Baumol (2000), among others. Baumol (2000), for instance, claims that "[in economics], the century has been full of accomplishments. New ideas, new directions, and powerful new tools have emerged in the profession. Evidently, our field of study is alive and well” (p. 38). Likewise, Summers (2000), who served as U.S. Secretary of the Treasury (1999-2001) and as President of Harvard University (2001-2006), believes that “(w)hat economists think, say, and do has profound implications for the lives of literally billions of their fellow citizens” (p. 1).

Yet it remains difficult, perhaps even impossible, to empirically analyze the extent to 
which these strongly contrasting views apply, not least because there exists no single distinguishable "economic view" that can be acted upon (for a more complete discussion, see Frey 2006). Indeed, economists even struggle to find a consensus about what constitutes "economics." 3 At the same time, the positions upon which economists largely agree are viewed with skepticism by the wider public. For instance, a recent study by Sapienza and Zingales (2013) identifies a considerable gap (an average of 37 percentage points) between the proportion of economists versus average Americans that agree with particular policyrelevant questions. The authors further show that this difference is largest for questions on which economists are most in consensus (p. 1). The term "influence" is also problematic in that it suggests a unidirectional impact of economics on society, even though society also clearly influences economics. In the extreme, it may be argued that economists simply reformulate (often via mathematical models) what is already common currency in the public discourse. It is also possible that even if economics and economists do indeed influence society, such influence may take hold only over an extended and unknown time period (see Colander and Coats 1989).

We explore this issue of social influence by examining the relation between academic economists' internal and external influences, specifically, the extent to which the importance ascribed to economists within academia (based on number of publications and citations) is reflected in their external influence, as reflected by mentions on Internet search engines (particularly, Google and Bing).

The remainder of the paper is arranged as follows. First, Section II puts our approach in perspective, summarizing the various ways in which a scholar's external influence may be captured. Section III describes our measure for external influence, which is based on the number of pages indexed on Google and Bing. Section IV then reports our results, and Section V concludes the paper.

\section{CAPTURING THE EXTERNAL INFLUENCE OF ECONOMICS AND ECONOMISTS}

To our knowledge, there are no systematic empirical studies comparing academic economists' internal and external rankings except for one study that measures the external influence of

\footnotetext{
${ }^{3}$ As referenced in Frey (2006), see Brittan (1973) and Machin and Oswald (1999) for the United Kingdom; for the United States, see Kearl et al. (1979) and Alston et al. (1992); for several European countries including France, Germany, Austria, and Switzerland, see Frey et al. (1984). van Dalen and Klamer (1997) also discuss the views of various schools of economics in the Netherlands, while Samuels (1980) and Fuchs, Krueger, and Poterba (1997) evaluate the consensus with respect to public finance and foreign trade issues.
} 
management scholars in the U.S. (Aguinis et al. 2012). This latter finds that a scholar's standing within the community of management scholars (as measured by citations in academic publications) deviates significantly and often to a high degree dependent on social attention (as measured by Web pages on Google). It is therefore unwarranted to assume that a researcher well-known in academia is also recognized outside academia and vice versa: some management scholars prominent outside academia (among them best-selling authors) are rarely if ever cited in academic publications.

Moreover, despite a wealth of literature on the possibilities and pitfalls of measuring research quantity and quality based on publications and citations (e.g., Cole and Cole 1971, Lindsey 1980, van Dalen and Klamer 2005, Coupé, Ginsburgh, and Noury 2010, Arrow et al. 2011, Johnston, Piatti, and Torgler 2013, Torgler and Piatti 2013), there is little research addressing the public attention received by economics and economists, probably because it is difficult to identify and measure. Most difficult to assess is the influence of economists and economics on society because all three terms - "influence," “economics,” and "economists” are not exactly defined and therefore difficult to measure empirically. Related discussions are thus largely descriptive rather than empirical, a problem that we attempt to remedy by distinguishing three different categories of processes that reflect the public influence of economists and economics.

\section{Reflections of the Influence on Markets}

\section{(1) Patents and Copyrights}

In some disciplines, mostly the natural sciences, a scholar's contributions to society are at least partly captured by the number of patents received and the income derived therefrom. However, despite a great deal of literature on this measure's adequacy and the many pitfalls involved (e.g., Trajtenberg 1990, Hall, Jaffe, and Trajtenberg 2001), the fact that patents play practically no role in economics eliminates them as a possible measure of outside impact for that discipline. Copyrights, on the other hand, are more relevant for economics because they refer to both books and articles in scientific journals and other outlets. Yet to our knowledge, there are no consistent data on this topic. Moreover, copyrights may be considered more an aid to producing and propagating economic ideas than an indicator of the extent of influence exerted. That is, the fact that an economist writes a bestseller and receives a high copyright income does not necessarily mean that his or her ideas have any direct influence. 
(2) Speaking Fees

Although scholars well-known to the public may demand higher monetary compensation for giving talks outside academia, such activity, albeit potentially influential, may serve primarily as entertainment with little, if any, social consequences. In addition, systematic data on such remuneration across countries is limited (Hosp and Schweinsberg 2006).

\section{(3) Advisory Activities}

One potentially useful indicator of economists' importance are the positions attained and income received by individuals appointed to expert panels. These positions range from membership of a high level economic advisory board (e.g., the Council of Economic Advisors in the U.S. or the Sachverständigenrat in Germany) to assuming advisory roles in ministries, nongovernmental organizations, and companies. Nevertheless, even though comprehensive statistics on such activities may exist for certain areas, and perhaps even countries, there is no database that would allow us to draw meaningful international comparisons.

\section{Reflections of the Influence on Persons}

(4) Former Students in the Private and Not-for-Profit Sector

Economic knowledge may be transferred to the public by former students who have become active outside academia; for instance, as CEOs and managers in private firms, as members of interest groups, or as participants in the voluntary sector. This type of influence, however, is difficult to capture because the underlying economic ideas are not necessarily expressed explicitly but rather may have been integrated into the alumni’s thinking and actions. Hence, although others may inculcate the economic ideas and further propagate them, this influence is difficult or even impossible to capture statistically. Admittedly, business school evaluations do try to capture alumni’s potential influence by measuring their subsequent income, yet usually only the starting salary is taken as an indicator of the value added to a person's educational capital. Obviously, this measure is incomplete and biased, particularly given the significant differences in average salary across different economic sectors. For instance, the salary of a graduate working in the financial sector tends to be much higher than that of a comparable graduate working in the non-profit sector. Hence, in an effort to develop a more useful ranking matrix, RePEc (Research Papers in Economics, see http://repec.org) has recently introduced the publication Geneology which allows individuals to provide information about their students and supervisors with the aim of assessing dissertation advisor 
and doctoral program quality. A recent poll by RePEc indicates that $54 \%$ of those responding are in favor of such a ranking (http://blog.repec.org, April 29, 2013).

(5) Politicians and Public Officials

Even when we restrict our attention to economics professors during recent years, we identify several economists who have achieved high ranks in politics and public administration. In the Netherlands, for example, Lubbers, Zijlstra, and De Quay were all prime ministers; Andriessen, Duisenberg, Witteveen, and Zahn were ministers of finance; and Pronk and Ritzen served as ministers in other departments. In Germany, Erhard was chancellor; Schiller was finance minister, and Töpfer and Hankel were heads of other ministries. In Italy, Prodi and Monti were prime ministers, and Einaudi was President of the Republic. In many countries, the position of the president of the central bank is normally occupied by a former professor of economics. We are, however, unaware of any reliable data on such positions especially given that such a database would necessarily cover all economists, not only professors.

\section{Reflections of the Influence on Outside Markets}

(6) References in Official Documents

Official documents offer two potentially effective measures of the extent to which researchers' contributions have actual policy implications: the first is the citation count in publications released by public bureaucracies and the second is the citation count in commissioned reports and similar materials.

\section{(7) Surveys}

The importance of a scholar outside academia can be usefully captured by surveying the general public (e.g., in popular journals) or such specific groups as public bureaucracies, special interest groups, and not-for-profit institutions.

(8) Awards

Scholars may also receive orders, medals, crosses, prizes, and other awards from institutions outside academia, as typified by the British Queen's appointment of scientists to the House of Lords. Because such honors signal the importance and quality of the recipient's work (Frey and Gallus 2013), we examine the relation between external influence and such key awards in 
economics by analyzing data on the Nobel Prize, the John Bates Clark Medal, and various fellowships (Fellow of the Econometric Society, AEA, or EEA ${ }^{4}$ ).

(9) Publications and Citations in the Popular Media

Members of academia may actively influence society by writing in newspapers or other press venues accessed by the public, including radio and television programs. Scholars may also passively influence the wider public via these channels if the topic's societal interest causes journalists to report on it.

(10) New Media

Scholarly activity by economists may also be reflected in one of the many new media avenues, including digitized books and newspaper articles, published mostly online, that are either written by scholars or cite their findings. Beyond these traditional publications reproduced on the Internet, influence may also be exerted via Twitter $^{5}$; online portals similar to VoxEU, on which economists present brief but socially relevant economic analyses; and economists’ blogs (e.g., “Marginal Revolution”), which are sometimes written in collaboration with nonacademics (e.g., "Freakonomics”). According to the Wall Street Journal, the most popular of these blogs can attract as many as 50,000 to 100,000 page views a day (Evans 2009). These new media, more than any other medium, are interactive and largely unregulated, meaning that persons from outside academia may engage in or launch discussions with economists. Users may thus multiply the reach of economic ideas by sharing and citing them within their social networks; for instance, on Twitter and Facebook or on their own blogs. Interestingly, according to the RePEc poll, 73\% of respondents argued against using Wikipedia mentions as citation counts for ranking purposes and 84\% were against doing so for blogs (http://blog.repec.org, April 29, 2013).

\footnotetext{
${ }^{4}$ See http://www.aeaweb.org/honors_awards/disting_fellows.php, http://www.aeaweb.org/honors_awards/foreign_hon_members.php, http://www.eeassoc.org/index.php?page=21 ${ }^{5}$ As of March 2013, for instance, Paul Krugman had over 970,000 followers, all with the potential to reproduce his commentary, and placed in the 99.75 percentile of the retweet ranking of all twitter accounts (http://www.retweetrank.com/NYTimeskrugman/\#).
} 


\section{Methodological Approach}

We gauge economists' influence outside academia ${ }^{6}$ by using web page counts from the widely used search engine Google (see, e.g., Sullivan 2013), which in 2012 had a global search engine market share of $81.56 \%$ for desktop searches and $90.88 \%$ for mobile/tablet search. $^{7}$ To ascertain the reliability of these counts as indicators of the importance attached by the general public to a particular economics scholar, we also employ counts from Bing (the Microsoft search engine) whose 2012 market share of desktop search and mobile search was $4.45 \%$ and $1.3 \%$, respectively. Nevertheless, we caution that ours is not the only possible measure for external impact and may not be suitable for other analyses of scholarly influence on society.

Our initial sample of academic economists was drawn from the September 2012 rankings in RePEc/IDEAS, the largest freely available bibliographic database on the Internet dedicated to economics and finance (http://ideas.repec.org). RePEc covers more than 34,000 registered academic researchers who are evaluated monthly on a range of publishing measures. We use RePEc's average rank score (which takes the harmonic mean of various rankings) to select the top 1,000 researchers (http://ideas.repec.org/top/top.person.all.html). Hence, our methodology mirrors Aguinis et al.'s (2012) use of current webometric techniques to explore the impact of web-based methods and online documents.

After first conducting searches using quotation marks around author names to avoid spurious matches (and thus incorrect crediting of webpage counts), we controlled for the validity of the sum of each individual count by running a single search in two versions of Google (the American google.com and the Swedish google.se). The total number of pages was identical for both versions, a consistency also reported for Aguinis et al.’s (2012) comparison of the American and Spanish versions. Next, to deal with any spurious matches generated by results that were clearly unrelated to the author in question, we employed Aguinis et al.'s (2012) criterion of 5\% spurious entries to exclude authors and increase the integrity of the data set. That is, for all 1,000 researchers, we manually checked the first 50 pages, and if three or more pages were not attributed to the author, we excluded this person from the sample. Finally, to alleviate any concerns about fluctuations in the count totals for Google pages, we ran four separate searches across an 18-day period (19 October to 6 November), with the first collection conducted manually by three research assistants over a 24 hour period on October 19.

\footnotetext{
${ }^{6}$ More specifically, we used web pages outside the “.edu” domain to operationalize external impact (see also Aguinis et al. 2012).

${ }^{7}$ http://marketshare.hitslink.com/report.aspx?qprid=12.
} 
From this initial manual search, we eliminated 274 of the 1,000 authors based on the 5\% criterion for nonattributed pages. During this manual collection, we also identified discrepancies between the spelling of an author name in RePEc (used purely to define and classify registered authors) and the actual name used in publications, which reflects the reality that many academics publish under more informal or more socially well-known names (e.g., “Mark L. Gertler” in RePEc appears as "Mark Gertler” on all his published work). In total, we identified 69 names with inconsistencies such as multiple middle names and extra or removed middle initials. Because any Google search for two different names (even for the same author) would result in a different page count, we excluded these cases from our data set to give a final sample of 723 researchers.

To extrapolate and aggregate the page counts for each individual, we relied on three automated computer searches taken directly from the Google and Bing Search APIs (application programming interfaces), ${ }^{8}$ which allow a large number of searches to be run simultaneously in a short amount of time. These three automated searches (on October 31, November 2, and November 6) not only ensured more robust data capture but also reduced the potential for human error.

The number of total search results reported in both the manual and the automatic count are only estimates (process not disclosed). The API searches, however, produce a significantly lower estimate than the manual searches. We can only speculate that results for the manual searches could be slightly inflated as to illustrate the search engine's extensive index, while the automatic search results reflect an underestimate based on the preliminary search. Hence, whereas the manual search returned a value of 5,410,000 pages for the researcher with the strongest external impact, the API returned only 922,667 pages (over an average of three search processes). Nevertheless, both values are highly correlated. To avoid limiting the search scope and to further the argument for capturing a wider social impact, we conducted all Google automated searches concurrently on the secondary search engine, Bing. The very high scale reliability coefficients (Cronbach's alpha) for our different count days (Google $=0.9998$, Bing $=0.9812)$ are comparable to those achieved by Aguinis et al. (2012) and justify computing an average based on the total number of Google or Bing entries across the three automatic data collection waves.

To construct a proxy for the impact inside academia, we use three measures provided by RePEc: total number of citations, total number of articles, and the h-index (which, for example, assigns a score of 30 when 30 of a scholar's papers have at least 30 citations each

\footnotetext{
${ }^{8}$ Available for a small fee.
} 
but his/her other papers have no more than 30 citations each). RePEc also provides a large set of ranking metrics with and without weighting over such factors as simple impact or number of authors (see http://ideas.repec.org/top/). It should, however, be noted that all RePEc values are rankings, and the higher the value, the lower the ranking. We also explore academic influence by evaluating academic recognition as reflected by the following awards and honors: the John Bates Clark Medal, the Nobel Prize, the Frisch Medal, Fellow of the Econometric Society, Fellow of the European Economic Association, Distinguished Fellow of the American Economic Association, or Foreign Honorary Member of the American Economic Association.

\section{Results}

Appendix Table A1 reports the most influential economists based on number of Google pages, together with the RePEc rankings and Bing page values (for comparative purposes). Nobel laureate Milton Friedman, who was a very active public figure, leads the list, followed by Nouriel Robini and Nobel laureate Amartya Sen. Nobel laureates Daniel Kahneman and Joseph Stiglitz are also in the top 10. In the top 20, we note Alvin Roth, who received the 2012 Nobel Prize in economics. Several researchers who combine academic research with policy making are also ranked highly, including Nouriel Roubini, who was active with the International Monetary Fund, the Federal Reserve, the World Bank, and the Bank of Israel and places second after Friedman. Likewise, Joseph Stiglitz, a John Bates Clark Medalist, former senior vice president and chief economist of the World Bank, and former member and Chairman of the Council of Economic Advisers ranks seventh, and Oliver Blanchard, chief economist at the International Monetary Fund, ranks eighth. Dani Rodrik, who has conducted substantial work on economic policy and government performance, ranks fourth. Ben Bernanke, chairman of the Federal Reserve, also appears in the top 20 list (at number 10) , as does Hans-Werner Sinn (at number 11), president of the IFO Institute for Economic Research, who since 1989 has also served on the Advisory Council of the German Ministry of Economics. Ranked at number 13 is Australian economist, John Quiggin, chief research economist with the Bureau of Agricultural Economics, board member of the Climate Change Authority of the Australian Government, and a very active blog writer. The top 20 also includes two other John Bates Clark Medalists, Steven Levitt (at number 15) and Daron Acemoglu (at number 17), who are also very successful book authors. Levitt’s Freakonomics 
and SuperFreakonomics, co-authored with Stephen Dubner, have received wide media and readership attention, leading to a blog, radio show, and movie (see http://www.freakonomics.com/), while Acemoglu’s Economic Origins of Dictatorship and Democracy, co-authored with James Robinson, accounts for more than 2,300 Google Scholar citations (as of July 28, 2013). Ranked at number 18 is Andrei Shleifer, also a John Bates Clark Medalist and a key figure in the Russian privatization process, who leads the RePEc ranking. Rounding out the list at number 20 is William Easterly, who has worked for 16 years as a researcher at the World Bank.

Appendix Figure A1 then presents two Lorenz curves that illustrate the inequality among scholars, reflecting Aguinis et al.’s (2012) assertion that individual performance can follow a power law distribution. In particular, although highly skewed distributions occur in a wide range of settings, they are particularly noticeable in biology, sociology, and economics (Simon 1955). In fact, power laws demonstrate that a few large entities drive most of the action and exist in many places, including firms, cities, academic institutions, and social networks (Barabási and Albert 1999, Barabási 2003). As a corollary, the winner-take-all principle suggests that minimal differences in individual performance are enough to generate huge outcome differentials (Rosen 1981, Frank and Cook 1995). The figure makes it abundantly clear that such inequality does indeed exist among scholars: $20 \%$ of those listed are responsible for around $70 \%$ of the Google pages. The Gini coefficient is similarly large (0.69 compared with 0.43) when Google is used instead of Bing, and the Google values are very close to those observed in sports (e.g., professional golf tournaments, see Fort 2003) ${ }^{9}$.

\footnotetext{
${ }^{9}$ On the other hand, Torgler and Piatti (2013) report values of 0.75 for the citation performance of American Economic Review articles between 1911 and 2010.
} 
FIGURE 1: RANKING DiFFERENCES BETWEEN INTERNAL AND EXTERNAL INFLUENCE
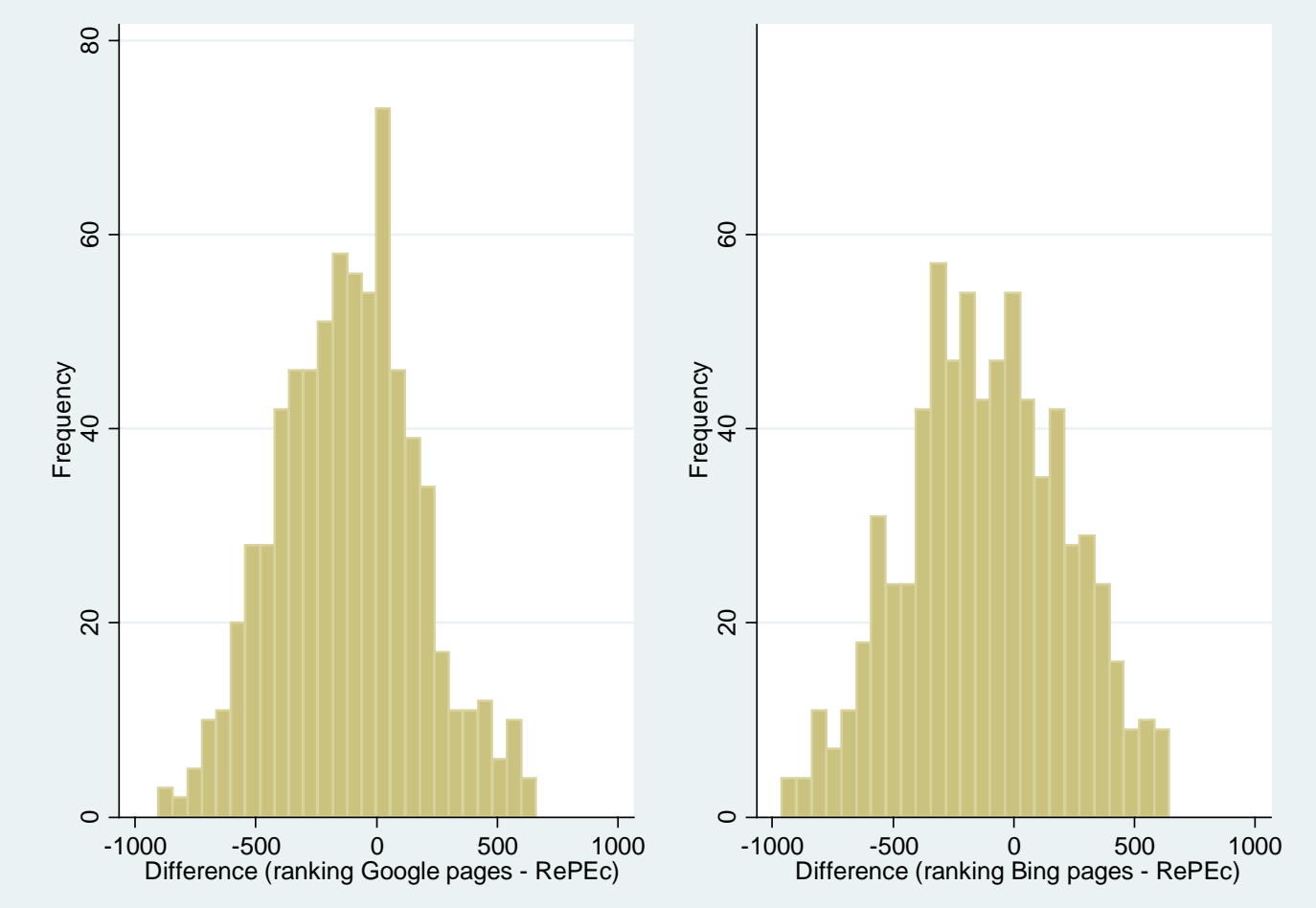

Figure 1 clearly illustrates the substantial (an average 115 rank) difference in positioning between Google and Bing and RePEc, which is similar to the 100 rank difference reported in Aguinis et al. (2012) for their comparison of citations and Google entries. In our data set, there is a difference between the two listings of over 200 ranks for $50.4 \%$ (57.82\%) of all scholars. Timothy Besley, for example, is ranked 72 in RePEc but only 620 based on Google counts. Similarly, Eugene Fama has a RePEc ranking of 52 but a Google ranking of only 660 . Conversely, Simon Kuznets has a RePEc ranking of 942 but a Google ranking of 64, while Reinhard Selten ranks at 806 in RePEc but as high as 75 on Google. Likewise, Ray Chetty (who recently received the John Bates Clark Medal) is ranked 878 on RePEc but 194 on Google. Hence, the histograms clearly indicate that high rankings based on internal academic evaluations can differ greatly from rankings based on social impact outside academia. Indeed, Aguinis et al. (2012) cite an anonymous review in Academy of Management Perspectives which claims that the results obtained "should give administrators pause” (p. 115). 
TABLE 1:

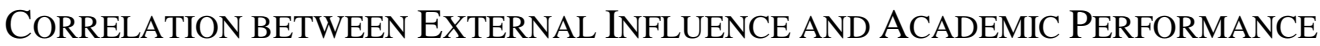

\begin{tabular}{|c|c|c|c|c|}
\hline & $\begin{array}{l}\text { Average: Google } \\
(\mathrm{N}=723)\end{array}$ & $\begin{array}{l}\text { Average: Bing } \\
(\mathrm{N}=723)\end{array}$ & $\begin{array}{l}\text { Average: Google } \\
\text { (top 100) }\end{array}$ & $\begin{array}{l}\text { Average: Bing } \\
\text { (top 100) }\end{array}$ \\
\hline RePEc ranking & $\begin{array}{l}-0.1454 \\
(0.0001)\end{array}$ & $\begin{array}{l}-0.1374 \\
(0.0002)\end{array}$ & $\begin{array}{l}-0.2875 \\
(0.0055)\end{array}$ & $\begin{array}{l}-0.1017 \\
(0.3346)\end{array}$ \\
\hline Number of distinct works & $\begin{array}{l}-0.0610 \\
(0.1011)\end{array}$ & $\begin{array}{l}-0.0804 \\
(0.0306)\end{array}$ & $\begin{array}{l}-0.1406 \\
(0.1814)\end{array}$ & $\begin{array}{l}-0.1087 \\
(0.3025)\end{array}$ \\
\hline $\begin{array}{l}\text { Number of distinct works } \\
\text { weighted by simple } \\
\text { impact factor }\end{array}$ & $\begin{array}{l}-0.0577 \\
(0.1210)\end{array}$ & $\begin{array}{l}-0.0870 \\
(0.0193)\end{array}$ & $\begin{array}{l}-0.0602 \\
0.5683\end{array}$ & $\begin{array}{l}0.0125 \\
0.9058\end{array}$ \\
\hline $\begin{array}{l}\text { Number of distinct works } \\
\text { weighted by number of } \\
\text { authors and simple } \\
\text { impact factor }\end{array}$ & $\begin{array}{l}-0.0689 \\
(0.0641)\end{array}$ & $\begin{array}{l}-0.1059 \\
(0.0044)\end{array}$ & $\begin{array}{l}-0.0594 \\
(0.5736)\end{array}$ & $\begin{array}{l}-0.0702 \\
(0.5063)\end{array}$ \\
\hline $\begin{array}{l}\text { Number of journal } \\
\text { pages }\end{array}$ & $\begin{array}{l}-0.0184 \\
(0.6218)\end{array}$ & $\begin{array}{l}-0.0451 \\
(0.2261)\end{array}$ & $\begin{array}{l}0.0163 \\
(0.8773)\end{array}$ & $\begin{array}{l}-0.0599 \\
(0.5707)\end{array}$ \\
\hline $\begin{array}{l}\text { Number of journal } \\
\text { pages weighted by simple } \\
\text { impact factor }\end{array}$ & $\begin{array}{l}-0.0306 \\
(0.4118)\end{array}$ & $\begin{array}{l}-0.0701 \\
(0.0596)\end{array}$ & $\begin{array}{l}0.2211 \\
(0.0342)\end{array}$ & $\begin{array}{l}-0.0346 \\
(0.7431)\end{array}$ \\
\hline $\begin{array}{l}\text { Number of journal } \\
\text { pages weighted by } \\
\text { number of authors and } \\
\text { simple impact factor }\end{array}$ & $\begin{array}{l}-0.0347 \\
(0.3512)\end{array}$ & $\begin{array}{l}-0.0804 \\
(0.0306)\end{array}$ & $\begin{array}{l}0.2894 \\
(0.0051)\end{array}$ & $\begin{array}{l}-0.095 \\
(0.3676)\end{array}$ \\
\hline Number of citations & $\begin{array}{l}-0.0566 \\
(0.1282)\end{array}$ & $\begin{array}{l}-0.0729 \\
(0.050)\end{array}$ & $\begin{array}{l}-0.0215 \\
(0.839)\end{array}$ & $\begin{array}{l}0.0249 \\
(0.8141)\end{array}$ \\
\hline $\begin{array}{l}\text { Number of citations } \\
\text { weighted by simple } \\
\text { impact factor }\end{array}$ & $\begin{array}{l}-0.0500 \\
(0.1791)\end{array}$ & $\begin{array}{l}-0.0729 \\
(0.0501)\end{array}$ & $\begin{array}{l}0.0061 \\
(0.9539)\end{array}$ & $\begin{array}{l}0.0161 \\
(0.8788)\end{array}$ \\
\hline $\begin{array}{l}\text { Number of citations } \\
\text { weighted by number of } \\
\text { authors and simple impact } \\
\text { factor }\end{array}$ & $\begin{array}{l}-0.0557 \\
(0.1343)\end{array}$ & $\begin{array}{l}-0.0846 \\
(0.0229)\end{array}$ & $\begin{array}{l}0.0372 \\
(0.7249)\end{array}$ & $\begin{array}{l}0.0054 \\
(0.9589)\end{array}$ \\
\hline h-index & $\begin{array}{l}-0.056 \\
(0.1328)\end{array}$ & $\begin{array}{l}-0.0683 \\
(0.0666)\end{array}$ & $\begin{array}{l}0.0007 \\
(0.9945)\end{array}$ & $\begin{array}{l}0.0200 \\
(0.8499)\end{array}$ \\
\hline
\end{tabular}

To assess the validity of this initial insight, in Table 1 we present an overview of the correlations between external influence and a large set of academic performance metrics taken 
from RePEc. It should be noted, however, that whereas these latter are rankings, we now use actual values for the Google and Bing pages, with higher values signaling lower performance. For Google, the striking outcome is that none of these academic performance metrics are significantly correlated with external influence except for the overall RePEc ranking, which returns a correlation of 0.146 and is statistically significant at the $1 \%$ level. Interestingly, this correlation is similar to that found by Aguinis et al. (2012) between Google entries and the number of citations (0.166) and articles (0.152) by management researchers. The Bing search, however, produces more significant factors with the expected sign, although the correlation is still quite low. It therefore seems that internal academic impact is only weakly correlated with external impact, meaning that the importance ascribed to an economist within academia is only partially reflected by the scholars’ external influence.

Obviously, our results could be subject to the criticism that exploring only the top 100 academics will produce different outcomes than a more general sample. Yet according to Table 2 this is not the case: compared to previous findings in which some academic performance proxies were statistically significant, none of the metrics shows a statistically significant correlation with the average number of Bing pages. For the Google pages, in contrast, we do find a positive and statistically significant correlation between the RePEc ranking and the number of journal pages weighted by simple impact factor, simple factor, or number of authors. Yet the RePEc scores can be criticized as lower-bound performance measures, because RePEc does not register all the economics journals. Rather, the citations are generated by extracting the list of references (http://citec.repec.org/) from each document made available to the RePEc digital library in electronic format, only around $74 \%$ of which have been analyzed so far because of software limitations in reference identification (PDFs must be converted to ASCII) and the related requirements that the documents must satisfy (http://citec.repec.org/warning.html). ${ }^{10}$

Accordingly, we also employed metrics from the Web of Knowledge and Publish or Perish (version 3), both used in fields beyond economics, the second of which enables the collection of a wide range of publishing metrics ${ }^{11}$ (see also Harzing 2010). Because many authors publish across different disciplines, we conducted both these searches with no constraints on journal of publication, thereby ensuring the capture of total internal academic impact not simply that related specifically to the author's primary field of research, and within a 72-hour period (from 1 March to 3 March, 2013) to ensure as little variation as possible over

\footnotetext{
${ }^{10}$ These electronically formatted documents are freely available on the Internet in either PostScript or PDF. The URLs refer to the document itself, not an intermediate abstract page.

${ }^{11}$ For a discussion, see http://www.harzing.com/pophelp/metrics.htm
} 
time. We did, however, still restrict our analysis to the top 100 economists in the RePEc rankings.

TABle 2: Correlation Between External Influence and Performance (ToP 100 RESEARCHERS)

\begin{tabular}{|c|c|c|}
\hline Publish or Perish & Average: Google & Average: Bing \\
\hline Citations & $\begin{array}{l}0.2361 \\
(0.0181)\end{array}$ & $\begin{array}{c}0.2928 \\
(0.0031)\end{array}$ \\
\hline Citations/years & $\begin{array}{l}0.2054 \\
(0.0403)\end{array}$ & $\begin{array}{c}0.2750 \\
(0.0056)\end{array}$ \\
\hline Citations/papers & $\begin{array}{l}-0.0125 \\
(0.9017)\end{array}$ & $\begin{array}{c}0.0287 \\
(0.7769)\end{array}$ \\
\hline $\begin{array}{l}\text { Average } N \text { papers per } \\
\text { author }\end{array}$ & $\begin{array}{l}-0.2187 \\
(0.0288)\end{array}$ & $\begin{array}{l}-0.2375 \\
(0.0174)\end{array}$ \\
\hline$h$-index & $\begin{array}{l}0.3005 \\
(0.0024)\end{array}$ & $\begin{array}{c}0.3938 \\
(0.0001)\end{array}$ \\
\hline$g$-index & $\begin{array}{l}0.2559 \\
(0.0102)\end{array}$ & $\begin{array}{c}0.3361 \\
(0.0006)\end{array}$ \\
\hline $\begin{array}{l}\text { hc-index } \\
\text { (Contemporary h-index) }\end{array}$ & $\begin{array}{l}0.2672 \\
(0.0072)\end{array}$ & $\begin{array}{c}0.3305 \\
(0.0008)\end{array}$ \\
\hline $\begin{array}{l}\text { hI-index } \\
\text { (Individual h-index) }\end{array}$ & $\begin{array}{l}0.4033 \\
(0.0000)\end{array}$ & $\begin{array}{c}0.4946 \\
(0.0000)\end{array}$ \\
\hline $\begin{array}{l}\text { hm-index } \\
\text { (Individual h-index) }\end{array}$ & $\begin{array}{l}0.3760 \\
(0.0001)\end{array}$ & $\begin{array}{c}0.4923 \\
(0.0000)\end{array}$ \\
\hline $\begin{array}{l}\text { AWCR } \\
\text { (Age-weighted citation rate) }\end{array}$ & $\begin{array}{l}0.1178 \\
(0.2433)\end{array}$ & $\begin{array}{c}0.1347 \\
(0.1815)\end{array}$ \\
\hline $\begin{array}{l}\text { AWCRpA (Normalised to the } \\
\text { number of author) }\end{array}$ & $\begin{array}{l}0.1695 \\
(0.0918)\end{array}$ & $\begin{array}{c}0.1827 \\
(0.0688)\end{array}$ \\
\hline$e$-index & $\begin{array}{l}0.2273 \\
(0.0230)\end{array}$ & $\begin{array}{c}0.2916 \\
(0.0032)\end{array}$ \\
\hline \multicolumn{3}{|l|}{ Web of Knowledge } \\
\hline Total citation count & $\begin{array}{l}0.0665 \\
(0.5112)\end{array}$ & $\begin{array}{l}0.0365 \\
(0.7184)\end{array}$ \\
\hline Average annual citation & $\begin{array}{l}0.0545 \\
(0.5905)\end{array}$ & $\begin{array}{c}0.0004 \\
(0.9971)\end{array}$ \\
\hline
\end{tabular}

Notes: The Publish or Perish metrics are described in detail in Harzing (2010) or at http://www.harzing.com/pop.htm

The Web of Knowledge data for these top 100 researchers only supports the earlier observation: there is no correlation between external influence and internal success. The Publish or Perish data, on the other hand, evince a more positive picture, although the 
correlations revealed by the metrics on age-weighted citation rate (AWCR) are not statistically significant or only border statistical significance. Rather, it is the different hindex scores that show the strongest correlation with external impact. Nevertheless, as with the Web of Knowledge data, the Publish or Perish results indicate that external influence is not correlated with the important success metric: citations per paper.

Table 3: Correlation Between External Influence and Prizes and Awards (N=723)

\begin{tabular}{l|ll}
\hline & Average: Google & Average: Bing \\
\hline JBC Medal & 0.2485 & 0.2118 \\
$(0.0000)$ & $(0.0000)$ \\
Nobel Prize & 0.2451 & 0.2905 \\
& $(0.0000)$ & $(0.0000)$ \\
Frisch Medal & -0.1091 & -0.0210 \\
& $(0.6109)$ & $(0.5737)$ \\
Distinguished & 0.0298 & 0.0977 \\
Fellow of the AEA & $(0.4234)$ & $(0.0086)$ \\
& & \\
Foreign Honorary & -0.0035 & 0.0010 \\
AEA & $(0.9251)$ & $(0.9777)$ \\
& & \\
Fellow of the & 0.0972 & 0.1375 \\
Econometric Society & $(0.0089)$ & $(0.0002)$ \\
& & \\
Fellow of the EEA & 0.0060 & 0.0270 \\
& $(0.8715)$ & $(0.4686)$ \\
Emeritus Fellow of & 0.1325 & 0.1416 \\
the EEA & $(0.0004)$ & $(0.0001)$ \\
& & \\
\hline
\end{tabular}

"Superstardom" is also evident in the extensive system of awards on which academia relies and which serves as a tool for distinction. The most renowned award after the Nobel Prize is the John Bates Clark Medal awarded to a scholar under 40 "who is judged to have made the most significant contribution to economic thought and knowledge." 12 Becoming a Fellow of the Econometric Society is also considered prestigious (Hamermesh and Schmidt 2003) despite their substantial number (877 by the end of 2011: Chan and Torgler 2012), and many John Bates Clark Medalists and Economic Society fellows later became Nobel laureates. The other awards, although also quite prestigious, can be classified as less important. Overall, external influence is positively linked to the level of the award's prestige, with the highest correlation observed for the Nobel Prize and the John Bates Clark Medal, although it is also

\footnotetext{
${ }^{12}$ http://www.aeaweb.org/honors_awards/clark_medal.php.
} 
significantly positively correlated with fellowship in the Econometric Society. In all other cases, however, there is barely any correlation.

Figure 3: GoOgle Trends For Nobel LAUREATES Before AND AFTER the NOBEL Prize

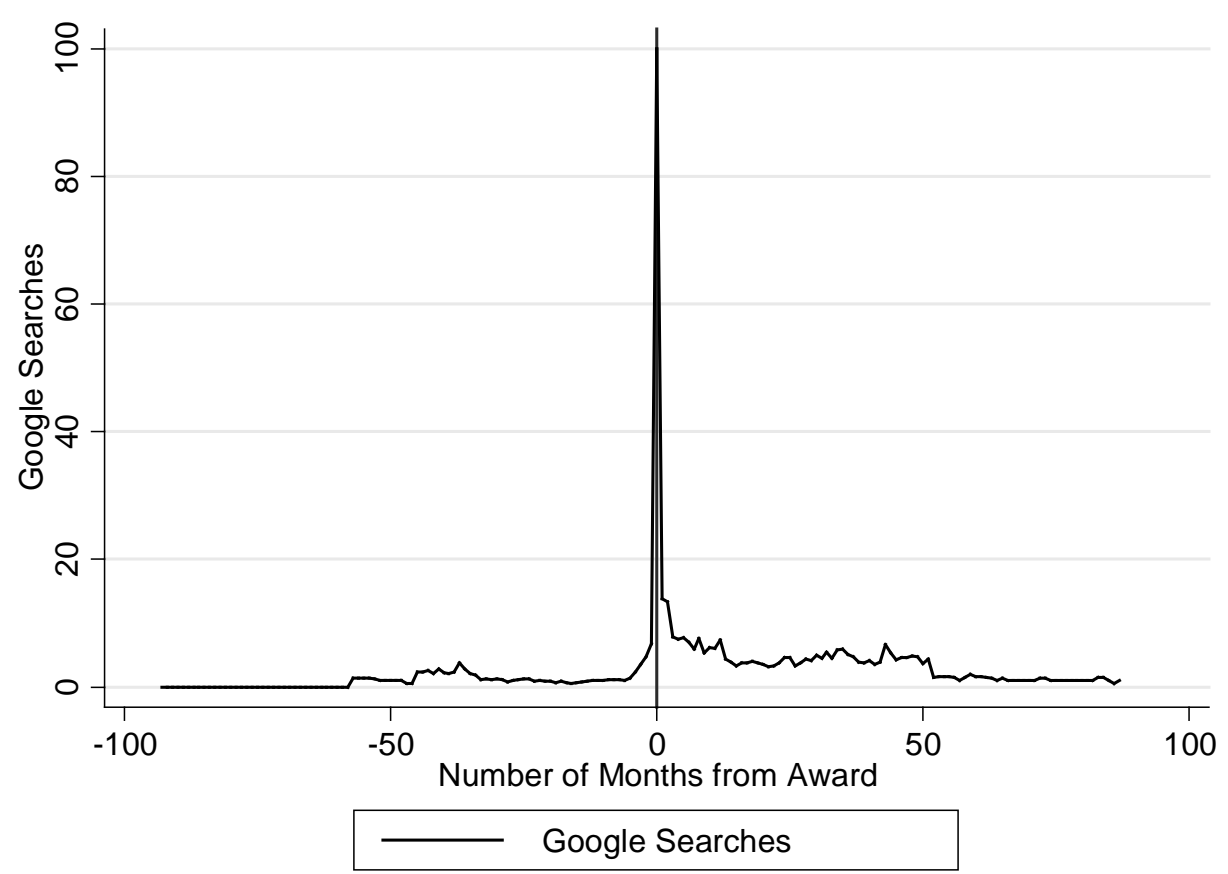

Figure 4: GoOgle Trends For John BAtes Clark MedAlists Before AND AFTER THE AWARD

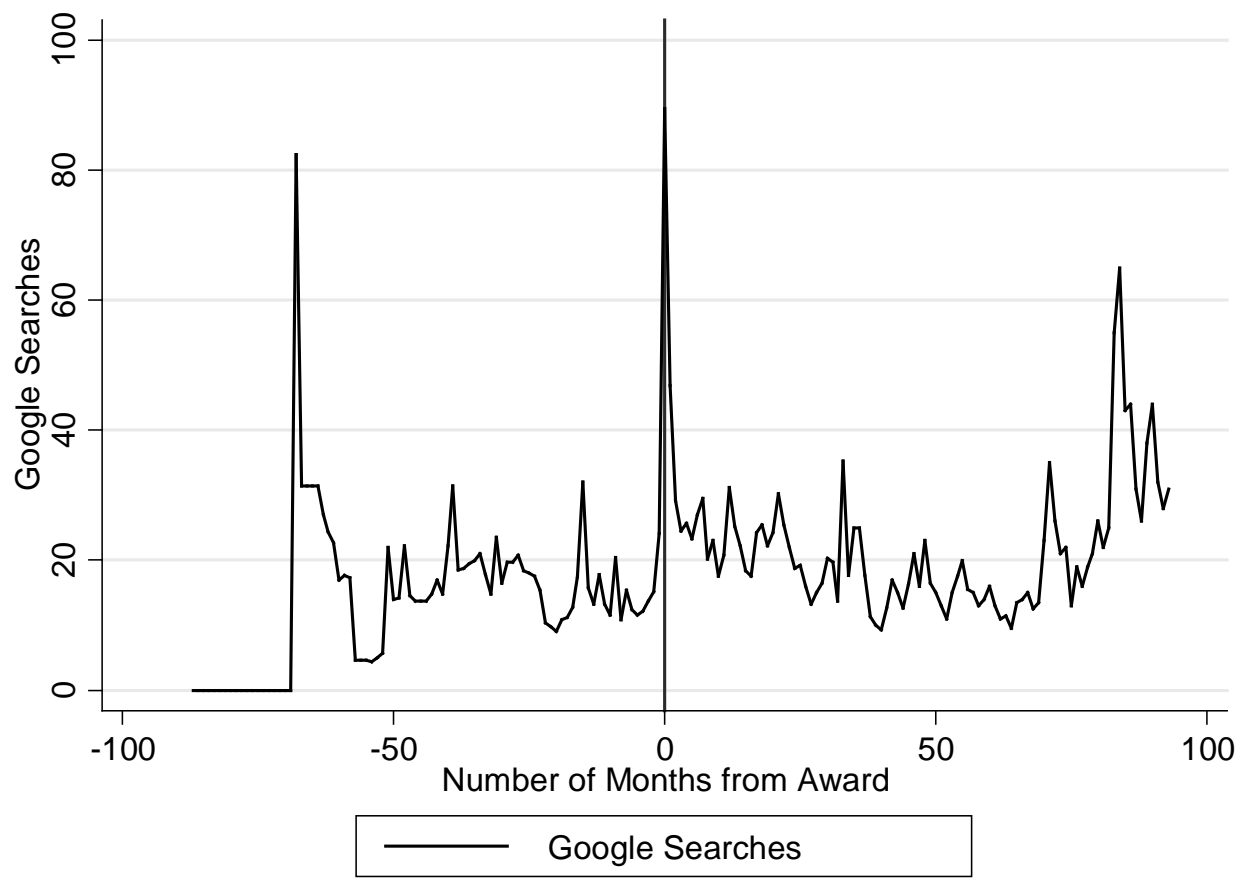


Nevertheless, it remains unclear whether these results are driven by the likelihood that the Nobel Prize or the John Bates Clark Medal will be given to a scholar with a strong external influence or by the fact that these awards actually have a positive impact on external influence. Figures 3 and 4 graph the results of a Google trend analysis conducted between 25 and 27 February, 2013, which extrapolated monthly search volume counts for each John Bates Clark Medalist $(\mathrm{N}=6)$ and Nobel laureate $(\mathrm{N}=16)$ receiving the award between January 2005 and January 2013 (a 97-month period). Although a massive peak is evident in the month in which the award was announced, the actual number of searches is not particularly large. Moreover, to our surprise, we observe more volatility over time among the John Bates Clark Medalists.

Subsequently, to correct for the possibility that external influence might be substantially driven by the social attention following award reception, we ran Google and Bing searches on whether each scholar is a John Bates Clark Medalist or Nobel Prize winner. We then subtracted these Google pages found from a normal name search result to eliminate the Google/Bing hits related to the award. The correlation values obtained (see Table A2) are higher than those derived earlier for Bing but lower for Google (in particular for Nobelists). The robustness of the results for the John Bates Clark Medalists could indicate that researchers with a higher external influence are more likely than other researchers to earn this prestigious medal.

We then conducted a multivariate analysis to check whether the correlations remained the same once other factors were controlled for. In particular, given the empirical evidence that educational background shapes academic researchers' career success (Chan and Torgler 2013), we examined how this background affects or even accentuates scholars' social impact. Again, we narrowed our performance criterion to researchers with a strong recent publication performance, defined as at least one publication in American Economic Review (AER), Econometrica, or Journal of Political Economy (JPE) between 2005 and 2010. From among the over 1,200 academics who published work in these three journals across the six-year period, we identified 193 out of the 723 academics in our revised RePEc top 1,000. We then collected the curriculum vitae for each of these academics, identifying their doctoral university and year of graduation and thus their academic age. To measure their university ranking position, we used the classification developed by Amir, Rabah, and Malgorzata Knauff (2008), which ranks the top 58 economics universities globally based not on research productivity but on the strength of the Ph.D. program as measured by the department's ability 
to place doctoral graduates in top-level economics departments or business schools. Because the ranking goes from 1 to 58, we classified all the universities with a constant value of 59, allowing us to create Top 10 and Top 20 dummies.

Table 4 presents the first set of results. The first two specifications, (1a) and (1b), are based on the 1 to 59 institutional ranking and include a dummy for whether a scholar is a John Bates Clark Medalist or Nobel laureate, while the next four contain dummies for Top 10 (2a and $2 \mathrm{~b}$ ) and Top 20 institutions (3a and 3b). In specifications (4a) and (4b), we also differentiate between John Bates Clark Medalists (JBCM) who are not Nobel laureates, Nobel laureates who are not John Bates Clark Medalists, and John Bates Clark Medalists who are also Nobel laureates. As the results clearly show, ceteris paribus, the recipients of these prestigious awards generate substantially more external influence (e.g., 1,780 more Google webpages) than all the other top researchers. The academics with the strongest performance are those who earned both the John Bates Clark Medal and the Nobel Prize. Again, however, the RePEc ranking is statistically significant only in the Google search process, never in the Bing analysis, a fact confirmed in Table 5 by the fact that none of the subfactor ranking variables are statistically significant in the Bing regressions. Interestingly, males seem to generate more external influence than females, but the institutional ranking of the doctoral university has no influence on external impact. In addition, when the Google pages are used as the dependent variable, our evaluation of a scholar's influence reveals a negative relation between external influence and academic age (years since Ph.D. or highest education), which may suggest that a less senior economics scholar can exert an important impact outside academia and so perhaps mitigate shortcomings such as fewer citations.

Our next analysis examined the major subfactors reported in Table 1 in place of the overall ranking information. As Table 5 shows, these subfactors, like the overall rankings, are not statistically significant, although when Google pages are the dependent variable, the citation proxies and weighted journal pages do reach statistical significance. Nor do these findings change in the robustness tests carried out using log Google and Bing values as the dependent variable: award recipients tend to have more external impact. 
TABLE 4: DETERMINANTS OF EXTERNAL INFLUENCE

\begin{tabular}{|c|c|c|c|c|c|c|c|c|}
\hline Dependent variable & $\begin{array}{l}\text { Google } \\
\text { (1a) }\end{array}$ & $\begin{array}{l}\text { Bing } \\
\text { (1b) }\end{array}$ & $\begin{array}{l}\text { Google } \\
(2 a)\end{array}$ & $\begin{array}{l}\text { Bing } \\
(2 b)\end{array}$ & $\begin{array}{l}\text { Google } \\
\text { (3a) }\end{array}$ & $\begin{array}{l}\text { Bing } \\
\text { (3b) }\end{array}$ & $\begin{array}{l}\text { Google } \\
(4 a)\end{array}$ & $\begin{array}{l}\text { Bing } \\
\text { (4b) }\end{array}$ \\
\hline \multirow[t]{2}{*}{ JBCM or Nobelist } & $17799.8 * * *$ & $1627.2^{* * *}$ & $17924.1 * * *$ & $1632.1^{* * *}$ & $17802.7^{* * *}$ & $1633.5^{* * *}$ & & \\
\hline & 3.12 & 5.14 & 3.16 & 5.17 & 3.14 & 5.16 & & \\
\hline JBCM but not & & & & & & & $26745.0 * *$ & $948.5^{*}$ \\
\hline Nobelist & & & & & & & 1.98 & 1.75 \\
\hline \multirow[t]{2}{*}{ Nobelist no JBCM } & & & & & & & $13742.7^{* * *}$ & $2114.5^{* * *}$ \\
\hline & & & & & & & 2.25 & 5.21 \\
\hline \multirow[t]{2}{*}{ JBCM and Nobelist } & & & & & & & $14249.2 * * *$ & $1108.7 * * *$ \\
\hline & & & & & & & 3.01 & 3.58 \\
\hline \multirow[t]{2}{*}{ RePEc ranking } & $-18.5^{* * *}$ & -0.3 & $-18.8^{* * *}$ & -0.3 & $-18.5^{* * *}$ & -0.3 & $-17.3^{* * *}$ & -0.4 \\
\hline & -4.94 & -1.1 & -5.05 & -1.2 & -4.87 & -1.18 & -4.69 & -1.5 \\
\hline \multirow[t]{2}{*}{ Male } & $6700.1 * * *$ & $618.6 * * *$ & $6571.9 * * *$ & $613.0 * * *$ & $6690.2^{* * *}$ & $618.1 * * *$ & $6512.8^{* * *}$ & $631.2 * * *$ \\
\hline & 3.75 & 2.8 & 3.71 & 2.77 & 3.8 & 2.8 & 3.69 & 2.87 \\
\hline Institutional & -3.1 & 0.00 & & & & & & \\
\hline Ranking & -0.08 & 0.00 & & & & & & \\
\hline \multirow[t]{2}{*}{ Top 10 institution } & & & -1007.8 & -48.1 & & & & \\
\hline & & & -0.56 & -0.31 & & & & \\
\hline \multirow[t]{2}{*}{ Top 20 institution } & & & & & 171.0 & -52.2 & -3.6 & -0.1 \\
\hline & & & & & 0.1 & -0.27 & -0.1 & -0.02 \\
\hline \multirow[t]{2}{*}{ Academic age } & $-272.5^{* * *}$ & -11.0 & $-275.0 * * *$ & -11.1 & $-272.9 * * *$ & -11.0 & $-204.7 * *$ & $-15.9 *$ \\
\hline & -2.72 & -1.32 & -2.77 & -1.35 & -2.73 & -1.34 & -2.54 & -1.81 \\
\hline $\mathrm{N}$ & 193 & 193 & 193 & 193 & 193 & 193 & 193 & 193 \\
\hline R-squared & 0.2499 & 0.1841 & 0.2508 & 0.1845 & 0.2499 & 0.1844 & 0.2614 & 0.2042 \\
\hline Prob > F & 0.000 & 0.000 & 0.000 & 0.000 & 0.000 & 0.000 & 0.000 & 0.000 \\
\hline
\end{tabular}

Notes: t-statistics in italics. The symbols *, ${ }^{* *},{ }^{* * *}$ represent statistical significance at the $10 \%, 5 \%$, and $1 \%$ levels, respectively. 
TABLE 5: RELATION BETWEEN INTERNAL AND EXTERNAL IMPACT

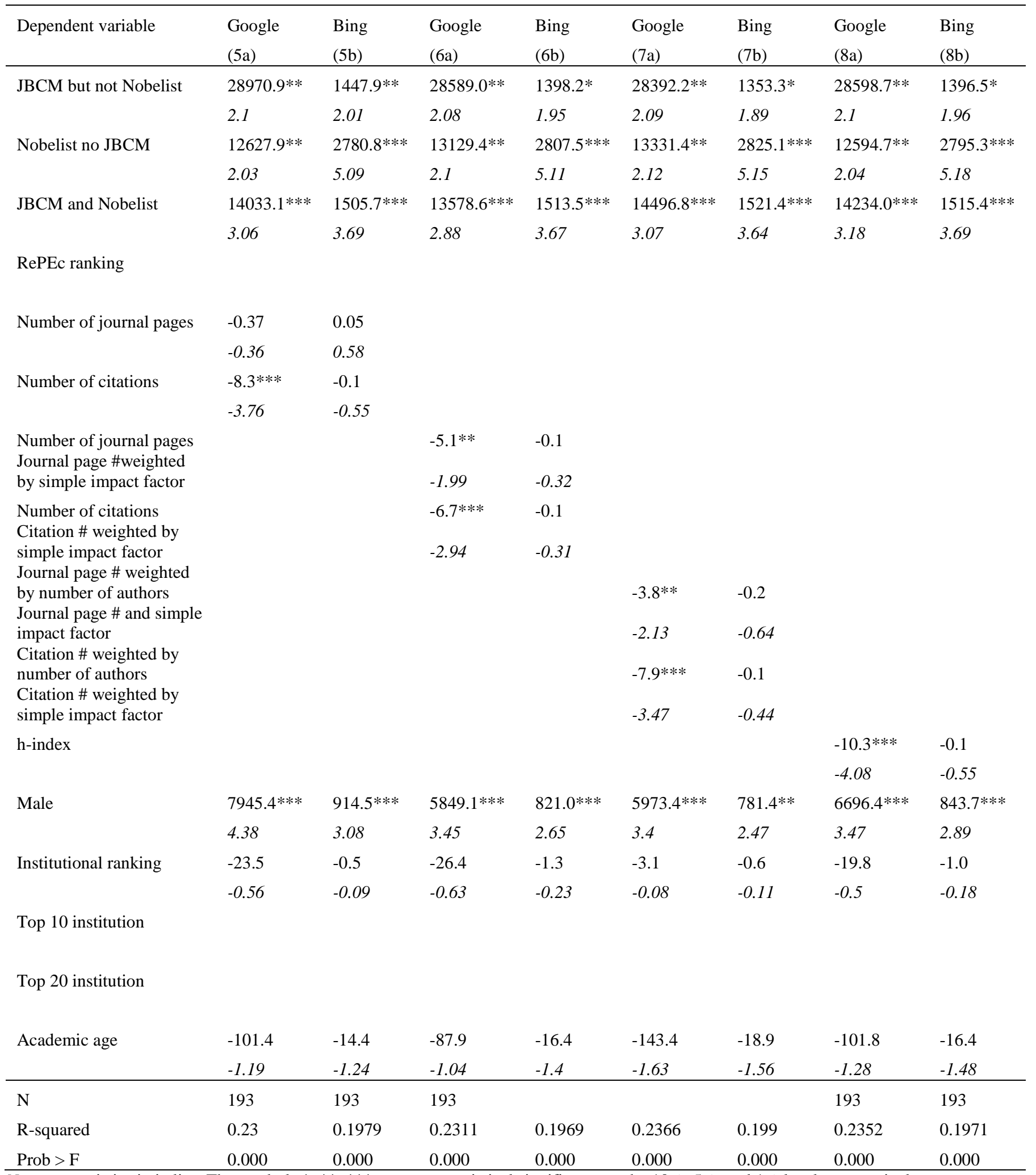

Notes: t-statistics in italics. The symbols *, **, *** represent statistical significance at the $10 \%, 5 \%$, and $1 \%$ levels, respectively. 


\section{Conclusions}

Measuring scholarly activity has emerged as an important topic, not least because of university administrators' strong incentives to find metrics for departmental progress, as well as academics' keenness to assess their relative professional standing and the quality of their university environment (Scott and Mitias 1996, Torgler and Piatti 2013). Yet to date academia has relied on a narrow set of internal factors such as publications or citations for its national and international comparisons. In reality, however, scholarly impact is multidimensional (Aguinis et al. 2012) and includes a variety of tasks. Academics, for example, can be categorized as either insiders or locals who are strongly involved in institutional services and in close interaction with members of the same university or as outsiders and cosmopolitans who bring new ideas, research quality, and outside prestige to the university through their research and activities in national and international professional organizations (Wilson 2013, Klahr 2004). Teaching and academic self-governance can also be classified as local activities despite the external influence later exerted by former students. Academic influence on the broader society, however, goes well beyond the local, especially in the face of new technologies that enable broader measurement of scholars' influence in the wider societal discourse. Yet little research has been done on scholars’ external influence, a void that this paper aims to fill by examining how internal influences within academia relate to these scholars' external influence.

Our analysis of the number of Google and Bing mentions of 723 economics scholars, however, reveals no, or only a low, correlation between external and internal influence. This result holds even though we employ a large set of metrics for internal influence, namely weighted and unweighted journal publications, citations, and the h-index. There is a difference between academic and external rankings of more than 200 positions for over $50 \%$ of the scholars in our data set. Moreover, the analysis of the top 100 researchers in RePEc shows no correlation between external influence and any of the academic performance variables measured, which echoes the overall findings of the Bing analysis. Nor does our alternative data source, the Web of Science, reveal any correlation between academic performance and external influence, although the results for the Publish or Perish data are somewhat more positive (correlations up to 0.403).

Overall, therefore, our results support Aguinis et al.'s (2012) findings for scholars in management: their impact within academia cannot be equated with their external influence. Rather, our examination of the impact of academic economists suggests that external 
influence is more strongly correlated with the reception of major awards like the John Bates Clark Medal and Nobel Prize. This finding remains robust for John Bates Clark Medalists even after we control for the external influence related to the awards.

Our findings raise many questions for future investigation, including how and why scholars achieve high levels of external influence. It would also be interesting to explore fluctuations over time, an approach made possible by the Google and Bing search engines. In addition, it will be worth exploring in more detail the other factors that capture external influence, such as new and popular media, official documents, patents, and former students.

\section{References}

Aguinis, H., Suarez-Gonzales, I., Lannelongue, G., Joo, H. (2012). Scholarly Impact Revisited. Academy of Management Perspectives 26(2): 105-132.

Alston, R. M., Kearl, J. R., Vaughan, M. B. (1992). Is There a Consensus among Economists in the 1990s? American Economic Review 82(2): 203-209.

Arrow, K. J., Bernheim, B. D., Feldstein, M. S., McFadden, D. L., Poterba, J. M., Solow, R. M. (2011). 100 Years of the American Economic Review: The Top 20 Articles. American Economic Review 101(1): 1-8.

Barabási, A. -L. (2003). Linked. How Everything Is Connected to Everything Else and What It Means for Business, Science, and Everyday Life. New York: A Plume Book.

Barabási, A. -L., Albert, R. (1999). Emergence of scaling in random networks. Science, 286 (October 15): 509-512.

Barro, R. J. (1996). Getting It Right: Markets and Choices in a Free Society. Cambridge: MIT Press.

Baumol, W. J. (2000). What Marshall Didn’t Know: On the Twentieth Century's Contributions to Economics. Quarterly Journal of Economics 115(1): 1-44.

Blaug, M. (1997). Ugly Currents in modern economics. Policy Options, Options Politiques 18(17): 3-8.

Brittan, S. (1973). Is There an Economic Consensus? An Attitude Survey. London: Macmillan.

Buchanan, J. M. (2000). Saving the Soul of Classical Economics. Wall Street Journal, January 1st.

Cassidy, J. (1996). The Decline of Economics. New Yorker, December 2nd. 
Chan, H. F., Torgler, B. (2012). Econometric Fellows and Nobel Laureates in Economics. Economics Bulletin 32(4): 3365-3377.

Clower, R. W. (1993). The State of Economics: Hopeless but Not Serious? in: D. Colander and A. W. Coats (eds.), The Spread of Economic Ideas. Cambridge: Cambridge University Press, pp. 23-30.

Coase, R. H. (1994). Essays on Economics and Economists. Chicago and London: Chicago University Press.

Colander, D. C., Coats, A.W. (eds.) (1989). The Spread of Economic Ideas. Cambridge: Cambridge University Press.

Cole, J., Cole, S. (1971). Measuring the Quality of Sociological Research: Problems in the use of the Science Citation Index. American Sociologist 6: 23-29.

Coupé, T., Ginsburgh, V., Noury, A. (2010). Are leading papers of better quality? Evidence from a natural experiment. Oxford Economic Papers 62(1): 1-11.

Dasgupta, P. (1998). Modern Economics and Its Critics. Mimeo, University of Cambridge.

Economist (1997). The Puzzling Failure of Economics. The Economist, August 23rd.

Economist (2000). Economics Forum: The Future of Economics. The Economist, March 4th.

Evans, K. (2009). The New Stars of the Blogosphere. The Wall Street Journal, July 16th. Available at:

http://online.wsj.com/article/SB10001424052970203739404574288793998936838.html. Last accessed March 6th, 2013.

Fort, R. D. (2003). Sports Economics. New Jersey: Prentice Hall.

Frank, R. H., Cook, P. J. (1996). The Winner-Take-All Society. New York: Free Press.

Frey, B. S. (2006). How influential is economics? De Economist 154(2): 295-311.

Frey, B. S., Gallus, J. (2013). Awards are a special kind of signal. Mimeo.

Frey, B. S., Pommerehne, W. W., Schneider, F., Gilbert, G. (1984). Consensus and Dissension among Economists: An Empirical Inquiry. American Economic Review 74(5): 986-994.

Friedman, M. (1986). Economists and Economic Policy. Economic Inquiry 14(1): 1-10.

Fuchs, V., Krueger, A. B., Poterba, J. M. (1997). Why Do Economists Disagree About Policy? The Roles of Beliefs About Parameters and Values. NBER Working Paper No. 6151, Washington DC.

Galbraith, J. K. (1975). Letter. The Times, July 16th. 
Hall, B. H., Jaffe, A. B., Trajtenberg, M. (2001). The NBER Patent Citations Data File: Lessons, Insights and Methodological Tools. WP 8498, National Bureau of Economic Research.

Hamermesh, D. S., Schmidt, P. J. (2003). The Determinants of Econometric Society Fellows Elections, Econometrica, 71(1): 399-407.

Hayek, F. A. (1991). On Being an Economist, in: W.W. Bartley and S. Kresge (eds.), The Trend of Economic History. Chicago: University of Chicago Press, pp. 35-48.

Hosp, G., Schweinsberg, K. (2006). Für eine Handvoll Euros: Der Markt für Vorträge zur Bewertung des Einflusses der Volkswirtschaftslehre. Perspektiven der Wirtschaftspolitik 7(4): 459-469.

Johnston, D., W., Piatti, M., Torgler, B. (2013). Citation Success over Time: Theory or Empirics?, Scientometrics. 95(3): 1023-1029.

Karier, T. (2010). Intellectual Capital: Forty Years of the Nobel Prize in Economics. Cambridge: Cambridge University Press.

Kearl, J. R., Pope, C. L., Whiting, B. C., Wimmer, L. T. (1979). A Confusion of Economists? American Economic Review 69(2): 28-37.

Keynes, J. M. (1936). The General Theory of Employment, Interest and Money. London: Macmillan.

Klahr, D. (2004). Encounters with the force of Herbert A. Simon, in: M. Augier and J. G. March (eds.), Models of a Man: Essays in Memory of Herbert A. Simon. Cambridge, MA: MIT Press, pp. 433-449.

Leontief, W. (1971). Theoretical Assumptions and Nonobserved Facts. American Economic Journal 61(1): 1-7.

Lindsey, D. (1980). Production and Citation Measures in the Sociology of Science: The Problem of Multiple Authorship. Social Studies of Science 10(2): 145-162.

Machin, S., Oswald, A. (1999). Signs of Disintegration: A Report on UK Economics PhDs and ESRC Studentship Demand. Report commissioned by the Economic and Social Research Council and associated organisations including the Bank of England and the Government Economic Service. Available at:

http://www2.warwick.ac.uk/fac/soc/economics/staff/academic/oswald/esrcrep.pdf. Accessed March 4th, 2013.

Nadeau, R. (2003). The Wealth of Nature. How Mainstream Economics Has Failed the Environment. New York: Columbia University Press.

Pierce, A. (2008). The Queen asks why no one saw the credit crunch coming. The Telegraph, November 5th. 
Rosen, S. (1981). The Economics of Superstars. The American Economic Review 71(5): 845858.

Sapienza, P., Singales L. (2013). Economic Experts vs Average American. Chicago Booth Research Paper No. 13-11.

Samuels, W. J. (1980). Economics as a Science and Its Relation to Policy: The Example of Free Trade. Journal of Economic Issues 14: 163-185.

Scott, L. C., Mitias P. M. (1996). Trends in Ranking of Economics Departments in the U.S.: An Update. Economic Inquiry 34(2): 378-400.

Simon, H. A. (1955). On a Class of Skew Distribution Functions. Biometrika 42(3/4): 425440.

Sullivan, Danny (2013). Google Still World's Most Popular Search Engine By Far, But Share Of Unique Searchers Dips Slightly. Search Engine Land, Feb 11th. Available at: http://searchengineland.com/google-worlds-most-popular-search-engine-148089.

Summers, L. H. (2000). International Financial Crises: Causes, Preventions and Cures. American Economic Review 90(2): 1-16.

Torgler, B., Piatti M. (2013). A Century of American Economic Review: Insights on Critical Factors in Journal Publishing. Hampshire: Palgrave/MacMillan.

Trajtenberg, M. (1990). A Penny for Your Quotes: Patent Citations and the Value of Innovations. RAND Journal of Economics 21(1): 172-187.

van Dalen, H. J., Klamer, A. (1997). Blood Is Thicker Than Water: Economists and the Tinbergen Legacy, in: P. A. G. van Bergeijk, A. L. Bovenberg, E. E. C. van Damme and J. van Sinderen (eds.), Economic Science and Practice: The Roles of Academic Economists and PolicyMakers. Cheltenham: Edward Elgar, pp. 60-91.

van Dalen, H. P., Klamer, A. (2005). Is Science a Case of Wasteful Competition? Kyklos 58(3): 395-414.

Wilson, E. O. (2013). Letters to a Young Scientist. New York: Liveright Publishing Corporation. 
TABLE A1: RANKING OF ECONOMIC SCHOlars using AVERAGE Number of PAGES

\begin{tabular}{|c|c|c|c|c|}
\hline Name & $\begin{array}{l}\text { Ranking: } \\
\text { Google }\end{array}$ & $\begin{array}{l}\text { Ranking: } \\
\text { Bing }\end{array}$ & $\begin{array}{l}\text { Ranking } \\
\text { RePec }\end{array}$ & $\begin{array}{l}\text { Average \# of } \\
\text { Google pages }\end{array}$ \\
\hline MILTON FRIEDMAN & 1 & 2 & 265 & 922667 \\
\hline NOURIEL ROUBINI & 2 & 1 & 596 & 712000 \\
\hline AMARTYA SEN & 3 & 5 & 231 & 412000 \\
\hline DANI RODRIK & 4 & 3 & 59 & 274000 \\
\hline CHRISTOPHER F. BAUM & 5 & 618 & 15 & 262000 \\
\hline DANIEL KAHNEMAN & 6 & 10 & 178 & 229667 \\
\hline JOSEPH E STIGLITZ & 7 & 4 & 3 & 222000 \\
\hline OLIVIER BLANCHARD & 8 & 19 & 12 & 153333 \\
\hline N GREGORY MANKIW & 9 & 55 & 32 & 122000 \\
\hline BEN S BERNANKE & 10 & 11 & 29 & 118000 \\
\hline HANS WERNER SINN & 11 & 7 & 143 & 111667 \\
\hline MICHELE BOLDRIN & 12 & 14 & 447 & 105333 \\
\hline JOHN QUIGGIN & 13 & 9 & 277 & 103667 \\
\hline ALVIN E ROTH & 14 & 17 & 117 & 79833 \\
\hline DARON ACEMOGLU & 15 & 41 & 6 & 70567 \\
\hline AUSTAN GOOLSBEE & 16 & 12 & 831 & 68267 \\
\hline STEVEN LEVITT & 17 & 27 & 189 & 67633 \\
\hline ANDREI SHLEIFER & 18 & 284 & 1 & 65933 \\
\hline KAUSHIK BASU & 19 & 6 & 367 & 62933 \\
\hline WILLIAM EASTERLY & 20 & 79 & 110 & 61300 \\
\hline LUIGI ZINGALES & 21 & 49 & 89 & 58767 \\
\hline ANDREU MAS COLELL & 22 & 15 & 678 & 49067 \\
\hline PAUL A SAMUELSON & 23 & 37 & 169 & 48433 \\
\hline LAWRENCE H. SUMMERS & 24 & 68 & 23 & 45800 \\
\hline ROBERT J. SHILLER & 25 & 113 & 82 & 44367 \\
\hline ESTHER DUFLO & 26 & 82 & 227 & 43733 \\
\hline LARS E. O. SVENSSON & 27 & 374 & 48 & 43700 \\
\hline JEAN TIROLE & 28 & 264 & 8 & 42967 \\
\hline LUCREZIA REICHLIN & 29 & 16 & 339 & 42833 \\
\hline JOHN B TAYLOR & 30 & 18 & 56 & 42833 \\
\hline JAMES POTERBA & 31 & 372 & 41 & 42033 \\
\hline JONATHAN GRUBER & 32 & 29 & 219 & 39333 \\
\hline TITO BOERI & 33 & 60 & 836 & 38767 \\
\hline FRANCO MODIGLIANI & 34 & 36 & 610 & 38700 \\
\hline XAVIER SALA IMARTIN & 35 & 35 & 152 & 38633 \\
\hline GARY GORTON & 36 & 91 & 331 & 38400 \\
\hline THOMAS PIKETTY & 37 & 31 & 613 & 38167 \\
\hline JOHN LIST & 38 & 23 & 77 & 38033 \\
\hline ROSS LEVINE & 39 & 299 & 25 & 37600 \\
\hline CHRISTOPHER SIMS & 40 & 24 & 53 & 36167 \\
\hline JUSTIN WOLFERS & 41 & 21 & 633 & 35867 \\
\hline ALBERTO ALESINA & 42 & 209 & 27 & 35400 \\
\hline MARK GERTLER & 43 & 290 & 16 & 35267 \\
\hline GARY S. BECKER & 44 & 176 & 20 & 35067 \\
\hline PATRICK HONOHAN & 45 & 20 & 919 & 34733 \\
\hline
\end{tabular}




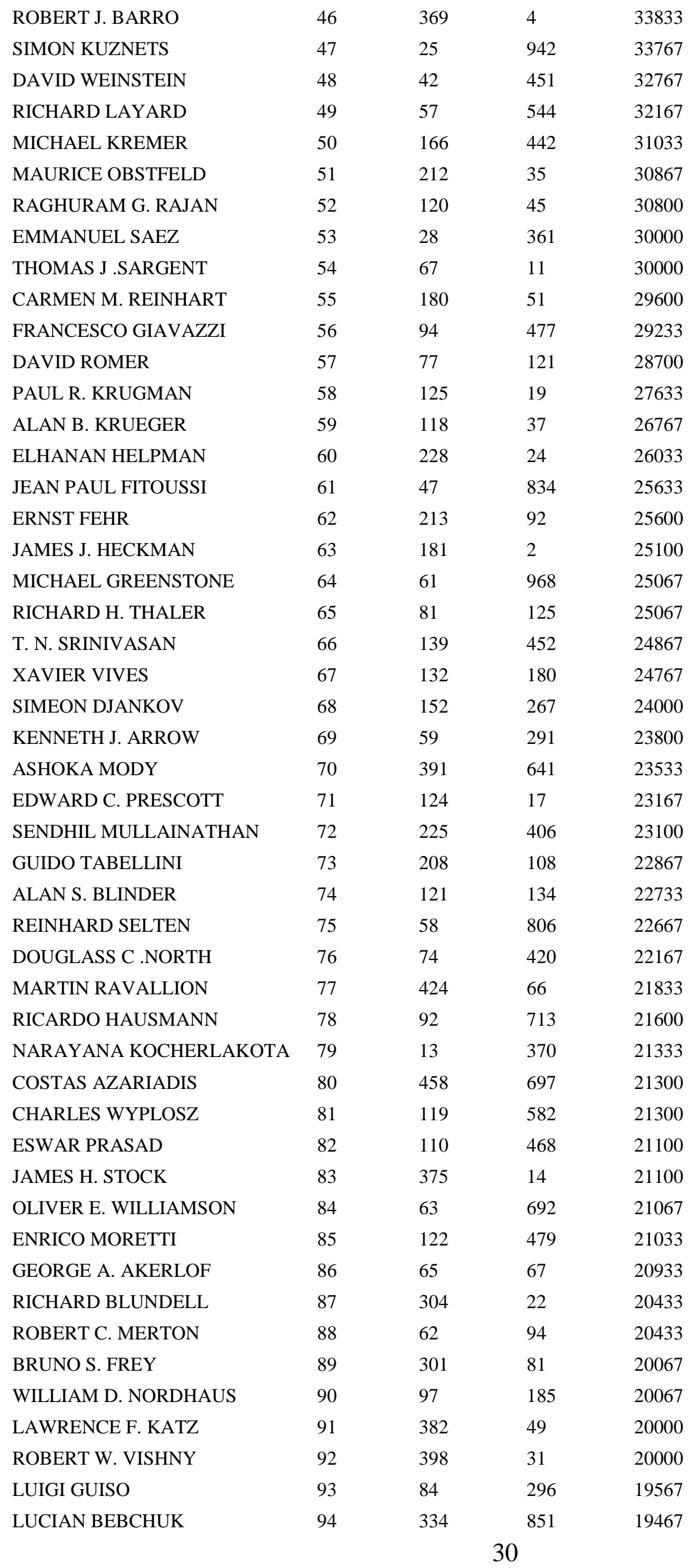




\begin{tabular}{lllll} 
SHERIDAN TITMAN & 95 & 238 & 238 & 19467 \\
CAMPBELL R. HARVEY & 96 & 447 & 149 & 19400 \\
EDUARDO LEVY YEYATI & 97 & 386 & 872 & 19367 \\
STEVEN SHAVELL & 98 & 230 & 491 & 19200 \\
ZVI GRILICHES & 99 & 249 & 88 & 19167 \\
GEORGE LOEWENSTEIN & 100 & 93 & 343 & 19133 \\
\hline
\end{tabular}

TABLE A2: CORRELATIONS BASED ON CORRECTED VALUES

\begin{tabular}{|c|c|c|c|}
\hline Searches & $\begin{array}{c}\text { Average: } \\
\text { Google }\end{array}$ & $\begin{array}{c}\text { Average: } \\
\text { Bing }\end{array}$ & Change \\
\hline \multicolumn{4}{|l|}{ John Bates Clark Medalists } \\
\hline “Name” - (“Name” + “John Bates Clark”) & $\begin{array}{l}0.1872 \\
(0.000)\end{array}$ & $\begin{array}{l}0.2675 \\
(0.000)\end{array}$ & $\downarrow(\mathrm{G}) \uparrow(\mathrm{B})$ \\
\hline "Name” - ("Name” + “John Bates Clark Medal”) & $\begin{array}{l}0.1848 \\
(0.000)\end{array}$ & $\begin{array}{l}0.2647 \\
(0.000)\end{array}$ & $\downarrow(\mathrm{G}) \uparrow(\mathrm{B})$ \\
\hline “Name” - (“Name” + “JBC Medal”) & $\begin{array}{l}0.1779 \\
(0.000)\end{array}$ & $\begin{array}{c}0.377 \\
(0.000)\end{array}$ & $\downarrow(\mathrm{G}) \uparrow(\mathrm{B})$ \\
\hline \multicolumn{4}{|l|}{ Nobel Prize Winners } \\
\hline “Name” - ( "Name”+ “Nobel”) & $\begin{array}{c}-0.1127 \\
(0.0024)\end{array}$ & $\begin{array}{l}0.3339 \\
(0.000)\end{array}$ & $\downarrow(\mathrm{G}) \uparrow(\mathrm{B})$ \\
\hline "Name” - ("Name + "Nobel Prize") & $\begin{array}{c}0.0770 \\
(0.0385)\end{array}$ & $\begin{array}{l}0.3425 \\
(0.000)\end{array}$ & $\downarrow(\mathrm{G}) \uparrow(\mathrm{B})$ \\
\hline
\end{tabular}


Figure A1: LORENZ CURVES
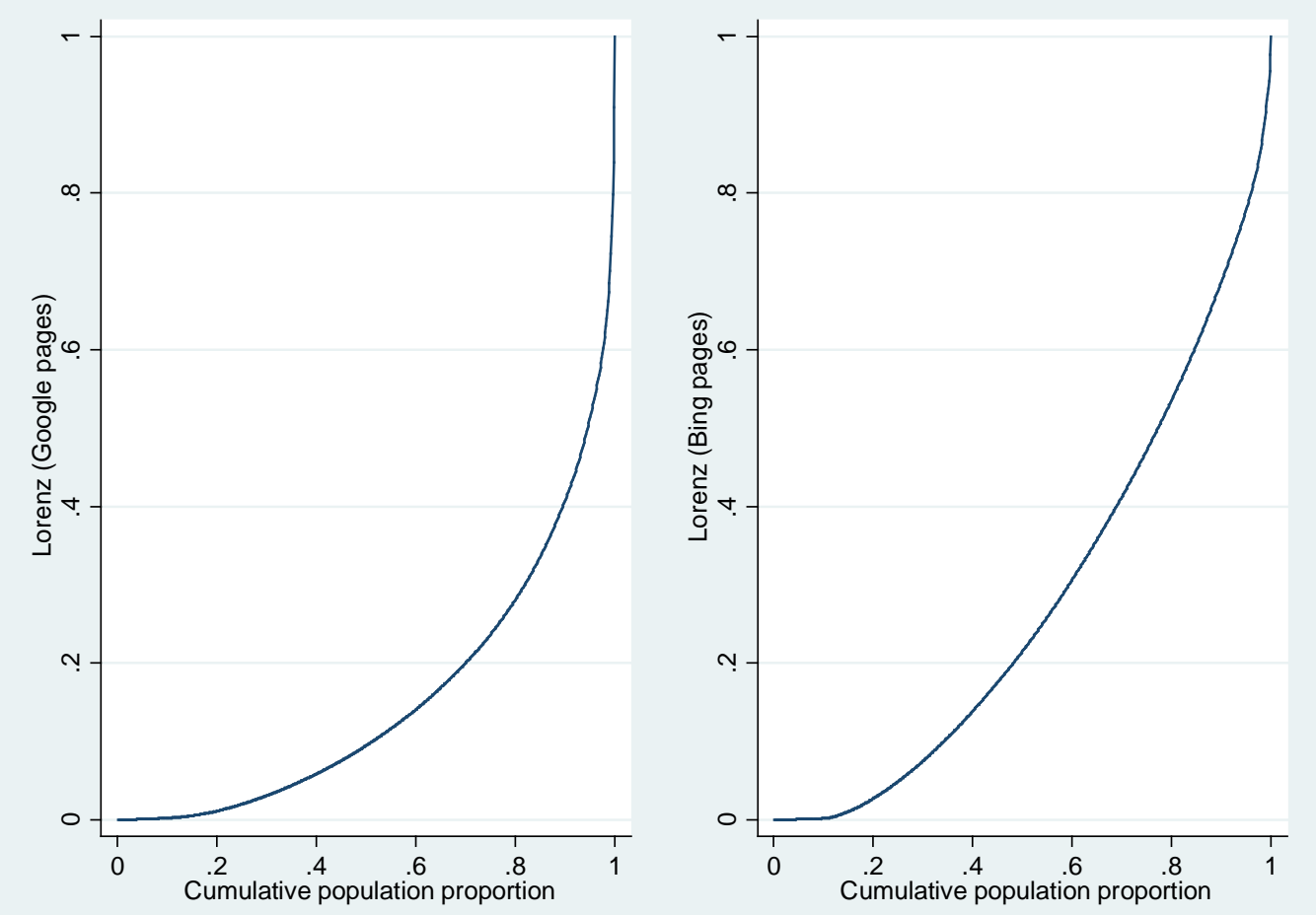